\title{
THIRD SYMPOSIUM ON APPLIED MATHEMATICS
}

The Third Annual Symposium on Applied Mathematics of the American Mathematical Society was held at the University of Michigan, Ann Arbor, Michigan, Tuesday to Thursday, June 14-16, 1949. The subject of the Symposium was Elasticity. Attendance at the sessions ranged from 70 to more than 200 . The following 133 persons, including 84 members of the Society, registered:

M. K. Al-Ghita, Maurice Anthony, R. C. F. Bartels, M. V. Barton, C. J. Blackall, F. E. Bothwell, F. C. Bragg, J. R. Britton, Bernard Budiansky, Jean Burnett, R. E. Carr, G. F. Carrier, K. V. Casey, Abraham Charnes, P. P. Chen, P. F. Chenea, R. V. Churchill, R. A. Clark, Nathaniel Coburn, C. J. Coe, H. G. Cohen, S. D. Conte, J. M. Crowley, N. C. Dahl, A. R. Decker, M. L. DeMoss, C. L. Dolph, L. H. Donnell, A. C. Downing, R. F. Dressler, D. C. Drucker, W. S. Ericksen, E. L. Eriksen, A. C. Eringen, F. D. Faulkner, G. S. Fenn, N. C. Fisk, J. S. Frame, D. M. Friedlen, K. O. Friedrichs, M. M. Frocht, I. M. Garfunkel, J. N. Goodier, L. E. Goodman, Lois Graham, D. F. Gunder, G. E. Hay, F. B. Hildebrand, T. H. Hildebrandt, H. H. Hilton, P. G. Hodge, D. L. Holl, C. C. Hurd, W. H. Ito, A. W. Jacobson, L. A. Jehn, Wilfred Kaplan, Leo Katz, Jean Kestens, W. M. Kincaid, J. T. Korkland, J. L. Lawrence, E. H. Lee, Harold Liebowitz, C. C. Lin, B. J. Lockhart, Duncan Luce, H. W. March, J. W. Marshall, H. L. Mason, E. F. Masur, Angelo Mennone, C. C. Miesse, Eugene Migotsky, R. D. Mindlin, M. V. Morkovin, E. J. Moulton, Manuel Murta, Douglas Muster, William Nash, E. A. Nordhaus, G. H. Nothmann, E. N. Oberg, W. R. Osgood, T. P. Palmer, W. H. Pell, Clay Perry, Hillel Poritsky, William Prager, Y. D. Prian, P. M. Quinlan, G. Y. Rainich, Herbert Reissmann, Eric Reissner, H. J. Reissner, M. M. Resnikoff, J. K. Riess, Felix Rosenthal, E. H. Rothe, T. R. Running, M. A. Sadowsky, Ward Sangren, Theodore Schiffman, H. M. Schwartz, B. R. Seth, H. S. C. Sharp, S. S. Shu, K. M. Siegel, Richard Skalak, W. K. Smith, I. S. Sokolnikoff, George Sonnemann, R. V. Southwell, F. L. Spitzer, Eli Sternberg, Marvin Stippes, J. J. Stoker, A. C. Sugar, P. C. Sweetland, P. S. Symonds, G. L. Thompson, C. J. Thorne, S. P. Timoshenko, H. M. Trent, Andrew Van Tuyl, E. G. Volterra, W. G. Warnoch, Alexander Weinstein, C. P. Wells, E. T. Welmers, A. W. Wundheiler, Dana Young, G. S. Young.

The Symposium was co-sponsored by the Applied Mechanics Division of the American Society of Mechanical Engineers which held its Fifteenth Applied Mechanics Division Conference at the University of Michigan, Monday to Wednesday, June 13-15.

The West Quadrangle Residence Halls and the Michigan Union of the University of Michigan together with the Cafeteria and Dining Room of the Michigan Union were available to those attending the Symposium and to their families.

Those attending the Symposium and the Applied Mechanics Division Conference and their families were guests of the Department of Mathematics at a lawn party near the campus on Tuesday evening.

Professor R. C. F. Bartels of the University of Michigan was in charge of local arrangements. 
The program of the Symposium consisted of one sixty-minute address, four forty-minute addresses, twelve twenty-minute addresses, all presented by invitation of the Committee on Program and Arrangements, and four thirty-minute addresses, one by title, contributed from the program of the Conference of the Applied Mechanics Division of the American Society of Mechanical Engineers. The programs on Tuesday and Thursday consisted of one morning and one afternoon session on each day. On Wednesday there were two morning sessions and one afternoon session. All three sessions on Wednesday were held jointly with the Applied Mechanics Division Conference. Each paper was followed by a discussion.

The twenty-one papers were presented in the following order:

1. Eric Reissner: On axi-symmetrical deformations of thin shells of revolution. (40 minutes)

2. H. W. March: The elastic stability of the facings of sandwich columns. (20 minutes)

3. J. J. Stoker: Pre-stressing of a plane circular plate to stiffen it against buckling. (20 minutes)

4. I. S. Sokolnikoff: An approximate method of solution of contact problems in anisotropic elasticity. (40 minutes)

5. Alexander Weinstein: New methods for the estimation of torsional rigidity. (20 minutes)

6. F. B. Hildebrand: On asymptotic integration in shell theory. (20 minutes)

7. T. J. Jaramillo: Deflections and moments due to a concentrated load on a cantilever plate of infinite length. (30 minutes) Presented by Professor Eli Sternberg.

8. C. C. Miesse: Determination of the buckling load for columns of variable stiffness. (30 minutes)

9. L. H. Donnell and C. C. Wan: Effect of imperfections on buckling of thin cylinders and columns under axial compression. (30 minutes) Presented by L. H. Donnell.

10. S. Dokos: $A$ force applied to the median plane at the center of a circular disk in a plate. (Presented by title)

11. Sir Richard Southwell: On the computation of strain and displacement in a prism plastically strained by torsion. (60 minutes)

12. William Prager and P. S. Symonds: Stress analysis in elasticplastic structures. (40 minutes) Presented by William Prager.

13. K. O. Friedrichs: Kirchhoff's boundary condition and the edge effect for elastic plates. (20 minutes)

14. G. E. Hay: Beams under concentrated loading. (20 minutes) 
15. B. R. Seth: Some recent applications of finite elastic deformation. (40 minutes)

16. G. F. Carrier and F. S. Shaw: Some problems in the bending of thin plates. (20 minutes) Presented by G. F. Carrier.

17. Nathaniel Coburn: $A$ graphical method for solving problems in plane plasticity. (20 minutes)

18. D. L. Holl: Dynamic loads on thin plates on elastic foundation. (20 minutes)

19. C. L. Perry: The bending of thin elliptic plates. (20 minutes)

20. Hillel Poritsky: Torsion problems with axial symmetry. (20 minutes)

21. E. H. Lee: On stress discontinuities in plane plastic flow. (20 minutes)

The presiding officers at the sessions were, respectively: Professors I. S. Sokolnikoff, William Prager, Dr. W. R. Osgood, Professors J. N. Goodier, D. L. Holl, K. O. Friedrichs, and Eric Reissner.

At the close of the Thursday afternoon session a resolution of thanks and appreciation to the University of Michigan for its hospitality was presented by Professor William Prager and unanimously approved.

All papers listed above except numbers 3 and 7 to 11 will be published as Vol. 3 of the Proceedings of a Symposia in Applied Mathematics. References will be given to the six papers not published in this volume.

$$
\text { R. V. Churchill, }
$$

Chairman of the Committee on Program and Arrangements

\author{
J. W. T. Youngs, \\ Associate Secretary of the Society
}

